\title{
Testing for Athlete
}

Citizenship 


\section{Critical Issues in Sport and Society}

\section{Michael Messner and Douglas Hartmann, Series Editors}

Critical Issues in Sport and Society features scholarly books that help expand our understanding of the new and myriad ways in which sport is intertwined with social life in the contemporary world. Using the tools of various scholarly disciplines, including sociology, anthropology, history, media studies and others, books in this series investigate the growing impact of sport and sportsrelated activities on various aspects of social life as well as key developments and changes in the sporting world and emerging sporting practices. Series authors produce groundbreaking research that brings empirical and applied work together with cultural critique and historical perspectives written in an engaging, accessible format.

Jules Boykoff, Activism and the Olympics: Dissent at the Games in Vancouver and London

Kathryn E. Henne, Testing for Athlete Citizenship: Regulating Doping and Sex in Sport

Jeffrey Montez de Oca, Discipline and Indulgence: College Football, Media, and the American Way of Life during the Cold War

Jennifer Guiliano, Indian Spectacle: College Mascots and the Anxiety of Modern America 


\section{Testing for Athlete Citizenship}

\section{Regulating Doping and Sex in Sport}

KATHRYN E. HENNE 
Library of Congress Cataloging-in-Publication Data

Henne, Kathryn E., 1982-

Testing for athlete citizenship : regulating doping and sex in sport / Kathryn Henne. pages $\mathrm{cm}$.-(Critical Issues in Sport and Society)

Includes bibliographical references and index.

ISBN 978-0-8135-6591-0 (hardcover : alk. paper)—ISBN (invalid)

978-0-8135-6590-3 (pbk. : alk. paper) -ISBN 978-0-8135-6592-7 (e-book)

I.Doping in sports. 2. Athletes-Drug use. 3. Athletes-Sexual behavior. I. Title.

$\mathrm{RC}_{1230} \mathrm{H}_{4} 62015$

$362.29^{\prime} 088796-\mathrm{dc} 23$

2014027495

A British Cataloging-in-Publication record for this book is available from the British Library.

Copyright $\left({ }^{2} 2015\right.$ by Kathryn Henne

All rights reserved

No part of this book may be reproduced or utilized in any form or by any means, electronic or mechanical, or by any information storage and retrieval system, without written permission from the publisher. Please contact Rutgers University Press, I06 Somerset Street, New Brunswick, NJ 0890 . The only exception to this prohibition is "fair use" as defined by U.S. copyright law.

Visit our website: http://rutgerspress.rutgers.edu

Manufactured in the United States of America 
To Andrew G. Nelson, who did not live to see this book in press but always told me that writing was in the family, and to Elizabeth L. Nelson, for first opening my eyes to places and worlds beyond my own. 
